\title{
Wpływ stopowania laserowego z użyciem nanorurek węglowych stopu Ti13Nb13Zr do zastosowań biomedycznych na jego wybrane własności mechaniczne
}

\author{
The influence of laser alloying with carbon nanotubes \\ of Ti13Nb13Zr on some of its mechanical properties \\ in biomedical application
}

\section{Streszczenie}

Do eksperymentu użyto stopu tytanu Ti13Nb13Zr, który ze względu na swój skład chemiczny i właściwości mechaniczne stanowi materiał do zastosowań $\mathrm{w}$ inżynierii medycznej. Celem pracy była ocena wpływu stopowania laserowego stopu Ti13Nb13Zr z powłoką z wielościennych nanorurek węglowych na jego właściwości mechaniczne (chropowatość, nanotwardość, moduł Younga). Do wytworzenia powłoki węglowej wykorzystano metodę osadzania elektroforetycznego (EDP). Modyfikację laserową przeprowadzono przy użyciu impulsowego lasera Nd:YAG. Zastosowano moc impulsu $800 \mathrm{~W}$ i czas impulsu 0,5 ms oraz $1 \mathrm{~ms}$. Właściwości mechaniczne zmierzono za pomocą nanoindentera, zaś chropowatość z użyciem mikroskopu sił atomowych (AFM). Zastosowanie powłoki z wielościennych nanorurek węglowych do stopowania laserowego stopu Ti13Nb13Zr oraz odpowiedni dobór parametrów procesu pozwoliły na podwyższenie właściwości mechanicznych (nanotwardość wzrosła ponad dwukrotnie) w stosunku do własności materiału rodzimego, nastąpiło również ujednolicenie właściwości w obrębie badanej powierzchni.

Stowa kluczowe: stopowanie laserowe; stop Ti13Nb13Zr; nanorurki węglowe; nanoindentacja
Abstract

The titanium alloy Ti13Nb13Zr was used as a substrate, because of its chemical composition and good mechanical properties in application of tissue engineering. The aim of the work was the assessment of the influence of laser alloying of Ti13Nb13Zr coated with multi-walled carbon nanotubes for mechanical properties (roughness, nanohardness, Young modulus). Electrophoretic deposition (EDP) method was used to prepare carbon coating. Laser modification was carried out with Nd:YAG laser in pulsed mode operating system. The power of the impulse was $800 \mathrm{~W}$ and the time $0,5 \mathrm{~ms}$ and $1 \mathrm{~ms}$. Mechanical properties were checked with nanoindenter and roughness of the surface with Atomic Force Microscope (AFM). The improvement of mechanical properties (the nanohardness increases more than twice) and its homogeneity within tested area (in the comparison to the native material) was seen after implementation of carbon nanotube coating with appropriate parameters of the process.

Keywords: laser alloying; titanium alloy Ti13Nb13Zr; carbon nanotubes; nanoindentation

\section{Wstęp}

Funkcjonalność implantu jest uzależniona od jego trwałości w środowisku płynów ustrojowych. W wyniku działających obciążeń mechanicznych oraz oddziaływania agresywnego środowiska implanty narażone są na procesy zużywania, takie jak pitting, fretting, uszkodzenia spowodowane zmęczeniem materiału oraz korozję. Zastosowanie odpowiednich powłok ochronnych ma na celu zwiększanie odporności na zużycie ścierne.
Ze względu na dobre właściwości smarne oraz stabilność chemiczną, materiałami mającymi duży potencjał ochronny są niektóre z odmian węgla pierwiastkowego. Ponadto, biomateriały węglowe cechuje:

- dobra biotolerancja w środowisku płynów ustrojowych,

- dobra hemozgodność; są to materiały atrombogenne (niesprzyjające powstawaniu skrzepów) - obojętne elektrycznie,

Mgr inż. Dorota Rogala-Wielgus, dr inż. Beata Majkowska-Marzec, mgr inż. Michał Bartmański - Politechnika Gdańska.

Autor korespondencyjny/Corresponding author: dorrogal@student.pg.edu.pl 
- bardzo dobra biokompatybilność,

- odporność na działanie promieniowania jonizującego i niejonizującego [1].

Nanorurki węglowe charakteryzuje duża przewodność cieplna i elektryczna, duża wytrzymałość na rozciąganie, stabilność termiczna i chemiczna, duża plastyczność, co sprawia, że mogą być wykorzystane w wielu dziedzinach życia $[2,3]$. Nanorurki węglowe charakteryzują się również dużą powierzchnią właściwą, która dla wielościennych nanorurek (MWCNTs, $z$ ang. multi-walled carbon nanotubes) wynosi $10 \div 20 \mathrm{~m}^{2} / \mathrm{g}$. Dzięki obecności pustego rdzenia wewnętrznego posiadają one małą gęstość w zakresie $1 \div 2 \mathrm{~g} / \mathrm{cm}^{3}$ [4]. Wytrzymałość nanorurek węglowych na rozciąganie jest nawet 100-krotnie większa niż dla stali, przy sześciokrotnie mniejszej masie. Podczas rozciągania długość nanorurki może zwiększyć się do $40 \%$, bez naruszenia jej struktury. Nanorurki węglowe charakteryzują się dużą sprężystością, stąd możliwe jest ich zginanie, skręcanie czy osiowe ściskanie [4]. Dlugon i współpracownicy badali właściwości nanorurek węglowych osadzonych elektroforetycznie na podłożu z Ti6Al4V. W wyniku nanoindentacji otrzymano twardość powłoki równą 1,66 GPa oraz moduł Younga wynoszący $101 \mathrm{GPa}$ [5].

W inżynierii tkankowej najczęściej stosowany jest stop Ti6Al4V. Istnieją jednak doniesienia o możliwych negatywnych skutkach uwalniania się składników stopowych tego materiału podczas eksploatacji. Wanad może wywoływać odczyny alergiczne oraz zaburzenia neurogenne, natomiast aluminium zmiękcza kości (główny czynnik osteoporotyczny), uszkadza komórki nerwowe (powiązania z chorobą Alzhaimera) oraz zaburza aktywność i funkcje wielu enzymów i neuroprzekaźników $[1,6,7]$. Stop Ti13Nb13Zr jest bezpieczniejszy dla organizmu. Pierwiastki, takie jak cyrkon czy niob, występujące $\mathrm{w}$ jego składzie powodują powstanie tlenków $\mathrm{ZrO}_{2}, \mathrm{Nb}_{2} \mathrm{O}_{5}$, które polepszają właściwości pasywne stopu, ponadto są one obojętne dla ludzkiego organizmu. Stop Ti13Nb13Zr charakteryzuje się lepszą wytrzymałością niż tytan do zastosowań medycznych oraz posiada niski moduł Younga (79 GPa), zbliżony do modułu sprężystości podłuż-

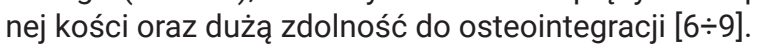

Osadzanie elektroforetyczne (EDP) jest jedną z metod otrzymywania powłok, która polega na osadzaniu na powierzchni elektrody (katody bądź anody) cząstek (naładowanych dodatnio lub ujemnie) zdyspergowanych w roztworze elektrolitu. Zaletą zastosowania metody EDP jest krótki czas nakładania powłoki, prosta aparatura oraz możliwość regulacji wielu parametrów (napięcie, czas, temperatura procesu, odległość między elektrodami itp.), dzięki czemu można wpływać na różnorodne właściwości otrzymanych powłok (grubość, morfologia) [10].

Tytan i jego stopy są metalami miękkimi - łatwo ulegają zniszczeniu, dlatego stosowane są powłoki ochronne. Połączenie obróbki laserowej z dodatkiem materiału z węgla pierwiastkowego powinno korzystnie wpłynąć na właściwości mechaniczne uzyskanej powierzchni. Wykorzystanie lasera do stopienia materiału powłokowego umożliwia regulację wieloma parametrami, takimi jak moc lasera, tryb pracy lasera, dzięki czemu można wpływać na właściwości mechaniczne obrabianego materiału. Co więcej, obróbka laserowa nie wymaga specjalnych warunków próżni, w porównaniu z metodami wykorzystującymi wiązkę jonów bądź elektronów $[11 \div 12]$. Przeprowadzono szereg badań dotyczących stopowania laserowego stopów tytanu węglem, węglikami, azotkami, borem, borkami $[11,13 \div 16]$, na podstawie których stwierdzono, że ten rodzaj obróbki poprawia własności wytrzymałościowe tytanu.

W niniejszej pracy zbadano właściwości mechaniczne stopu Ti13Nb13Zr z powłoką z wielościennych nanorurek węglowych, poddanych laserowej modyfikacji powierzchni. Sprawdzono wpływ czasu impulsu podczas obróbki laserowej oraz zastosowanego materiału stopowego na właściwości mechaniczne podłoża Ti13Nb13Zr.

\section{Materiały i metodyka obróbki laserowej}

Próbki do badań, w kształcie ćwierć-okręgów o promieniu $20 \mathrm{~mm}$ wycięto z pręta wykonanego ze stopu Ti13Nb13Zr o składzie chemicznym podanym w tablicy I.

Przed osadzeniem powłok z nanorurek węglowych powierzchnia płaska została odpowiednio zeszlifowana papierami ściernymi o malejącej gradacji, zgodnie z oznaczeniami papierów P120, P320, P500 i P800. Tak przygotowano próbkę z materiału rodzimego - referencyjną (MR). Próbki MR.laser.0,5ms oraz MR.laser.1ms po procesie szlifowania poddano obróbce laserowej zgodnie z parametrami podanymi w tablicy II. Dwie ostatnie próbki (MWCNTlaser.0,5ms i MWCNT.laser1ms) przed modyfikacją laserową poddano procesowi elektroforezy (EPD) w celu naniesienia powłoki $z$ wielościennych nanorurek węglowych.

Układ do EDP składał się z elektrody platynowej (katoda) oraz stopu Ti13Nb13Zr (anoda), które zostały zanurzone w $0,26 \%$ roztworze wodnym wielościennych nanorurek węglowych naładowanych ujemnie (3D-nano, PL-MCNP-1g, ilość ścian: $3 \div 15$, średnica zewnętrzna: $5 \div 20 \mathrm{~nm}$, średnica wewnętrzna: $2 \div 6 \mathrm{~nm}$, długość: $1 \div 10 \mu \mathrm{m}$ ). Proces przeprowadzono w ciągu 2 minut, w temperaturze pokojowej, przy napięciu 8 V. Próbki suszono w powietrzu przez 24h, a następnie modyfikowano za pomocą impulsowego lasera Nd:YAG (TruLaser Station 5004, TRUMPF) z parametrami przedstawionymi w tablicy II.

Tablica II. Parametry obróbki laserowej badanych materiałów Table II. Parameters of laser modification used to certain materials

\begin{tabular}{|c|c|c|}
\hline Oznaczenie próbki & $\begin{array}{c}\text { Moc lasera } \\
\text { (w impulsie) [W] }\end{array}$ & $\begin{array}{c}\text { Czas impulsu } \\
\text { [ms] }\end{array}$ \\
\hline MR.laser.0,5ms & 800 & 0,5 \\
\hline MR.laser.1ms & 800 & 1,0 \\
\hline MWCNT.laser.0,5ms & 800 & 0,5 \\
\hline MWCNT.laser.1ms & 800 & 1,0 \\
\hline
\end{tabular}

\section{Metodyka badań}

Topografię powierzchni próbek zobrazowano za pomocą mikroskopu sił atomowych (AFM, NaniteAFM, Wielka Brytania) z użyciem bezstykowego modułu z siłą $20 \mathrm{mN}$, na obszarze 80,4 x 80,4 $\mu \mathrm{m}$. Parametr chropowatości powierzchniowej Sa wyznaczony został za pomocą oprogramowania będącego integralną częścią urządzenia.

Tablica I. Skład chemiczny stopu tytanu Ti13Nb13Zr

Table I. Chemical composition of titanium alloy Ti13Nb13Zr

\begin{tabular}{|c|c|c|c|c|c|c|c|c|}
\hline \multicolumn{10}{|c|}{ Stężenie pierwiastków \% masowy } \\
\hline $\mathbf{N b}$ & $\mathbf{Z r}$ & $\mathbf{F e}$ & $\mathbf{C}$ & $\mathbf{H}$ & $\mathbf{0}$ & $\mathbf{S}$ & $\mathbf{H f}$ & $\mathbf{T i}$ \\
\hline 13,18 & 13,49 & 0,085 & 0,035 & 0,004 & 0,078 & $<0,001$ & 0,055 & reszta \\
\hline
\end{tabular}


Badania nanoindentacji wykonano z wykorzystaniem nanoindentera (NanoTest Vantage, Micro Materials, Wielka Brytania) z użyciem diamentowego, piramidalnego, trójściennego wgłębnika Berkovich'a o kącie wierzchołkowym równym $124,4^{\circ}$. Próbki poddano 25 (5 x 5) pomiarom nanoindentacji. Siła maksymalna wynosiła $50 \mathrm{mN}$, czas narastania siły od wartości zerowej wynosił $20 \mathrm{~s}$, czas zatrzymania z maksymalną wartością siły wynosił $10 \mathrm{~s}$, a czas odciążania $20 \mathrm{~s}$. Pojedyncze indentacje oddalone były od siebie o $50 \mu \mathrm{m}$. Podczas wykonywania pomiaru rejestrowana była krzywa zależności obciążenia od głębokości. Wartości twardości $(H)$, zredukowanego modułu Younga (Er) oraz modułu Younga (E) wyznaczono z wykorzystaniem metody Olivera-Pharra [17] z użyciem programu do analizy wyników NanoTest.

\section{Wyniki badań}

Rysunki $1 \div 3$ przedstawiają topografie powierzchni materiału rodzimego po szlifowaniu (MR), materiału modyfikowanego laserowo oraz materiału modyfikowanego laserowo z powłoką węglową, uzyskane za pomocą mikroskopu sił atomowych (AFM).

Stop Ti13Nb13Zr poddany szlifowaniu, a następnie obróbce laserem, niezależnie od czasu trwania impulsu (MR.laser.0,5ms i MR.laser.1ms) wykazuje wyższą chropowatość niż podłoże próbki referencyjnej (MR), co można zobaczyć porównując rysunek 1 i rysunek 2 .

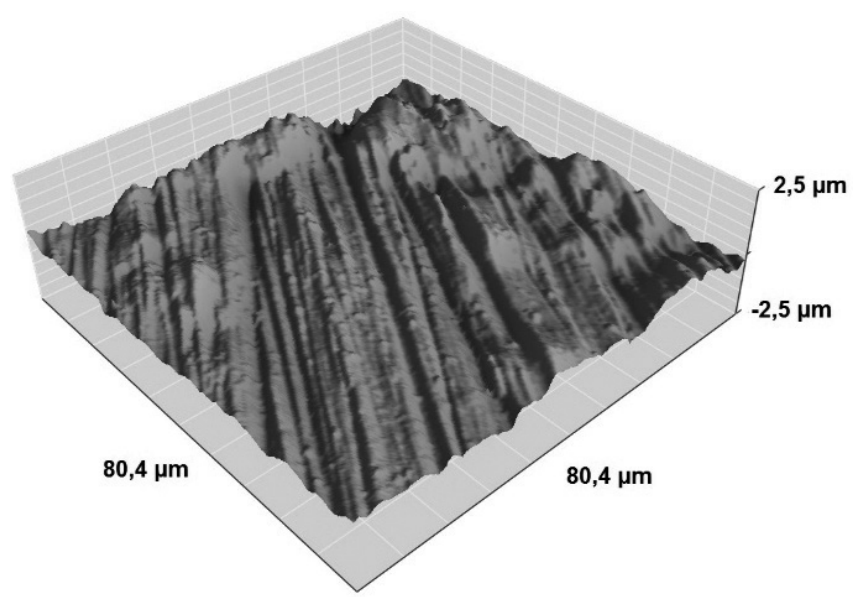

Rys. 1. Topografia powierzchni AFM próbki referencyjnej z materiału rodzimego po szlifowaniu (MR)

Fig. 1. AFM surface topography of the reference sample - native material after grinding (MR)

Największy wzrost chropowatości powierzchni w porównaniu z próbkami bez powłoki węglowej (rys. 1 i rys. 2) można zaobserwować dla próbki z wielościennymi nanorurkami węglowymi poddanymi obróbce laserowej o długości trwania impulsu 0,5 ms (MWCNT.laser.0,5ms). Powłoka z wielościennych nanorurek węglowych po obróbce laserowej o dłuższym czasie trwania impulsu (MWCNT.laser.1ms) wykazała znaczny spadek chropowatości.

Tablica III przestawia, jak zmienia się parametr chropowatości (Sa) w zależności od badanego materiału. Można zaobserwować tendencję próbek do obniżania chropowatości wraz z wydłużeniem czasu trwania impulsu. Najwyższą wartość parametru chropowatości uzyskano dla powłoki wielościennych nanorurek węglowych poddanych obróbce laserowej z impulsem o długości 0,5 ms, co potwierdzają też zdjęcia topografii próbki (rys. 3).

W wyniku przeprowadzonej nanoindentacji otrzymano wykresy zależności głębokości odkształcenia od zadanej
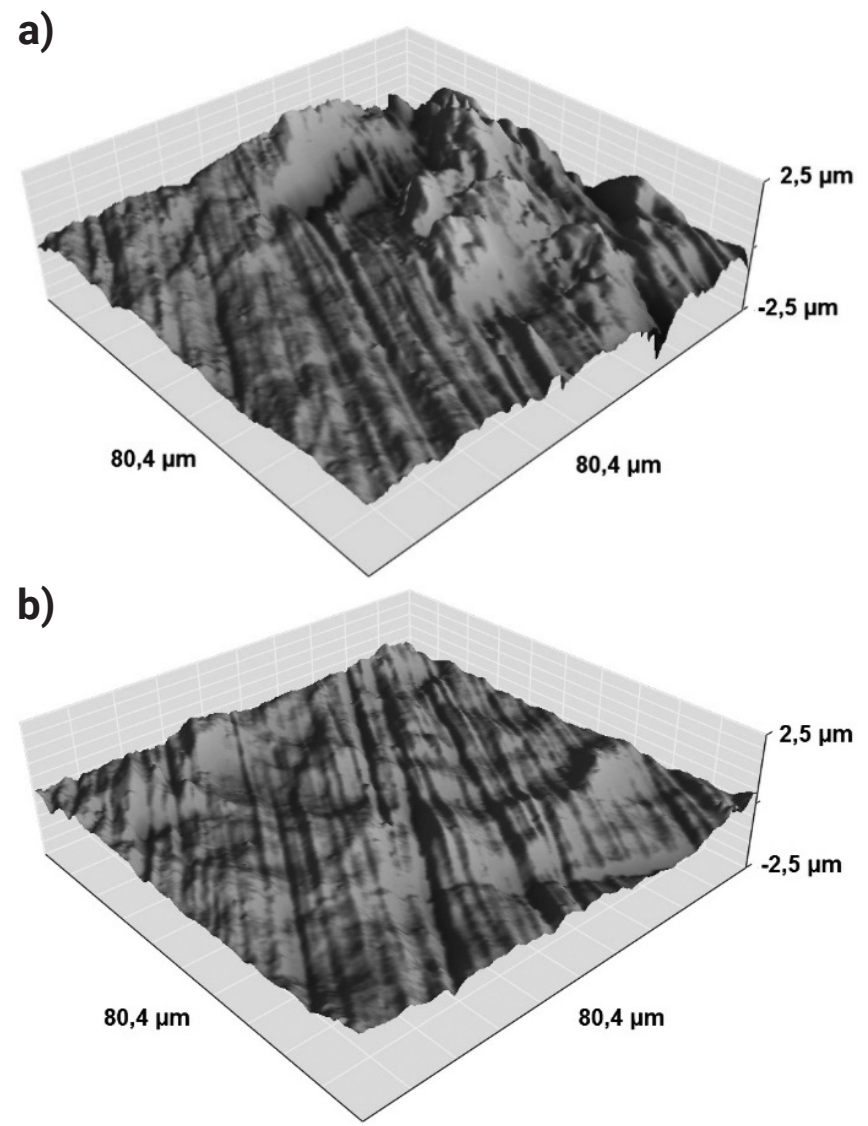

Rys. 2. Topografia powierzchni AFM próbki: a) MR.laser.0,5ms, b) MR.laser. $1 \mathrm{~ms}$

Fig. 2. AFM surface topography of the sample: a) MR.laser.0,5ms, b) MR.laser. $1 \mathrm{~ms}$
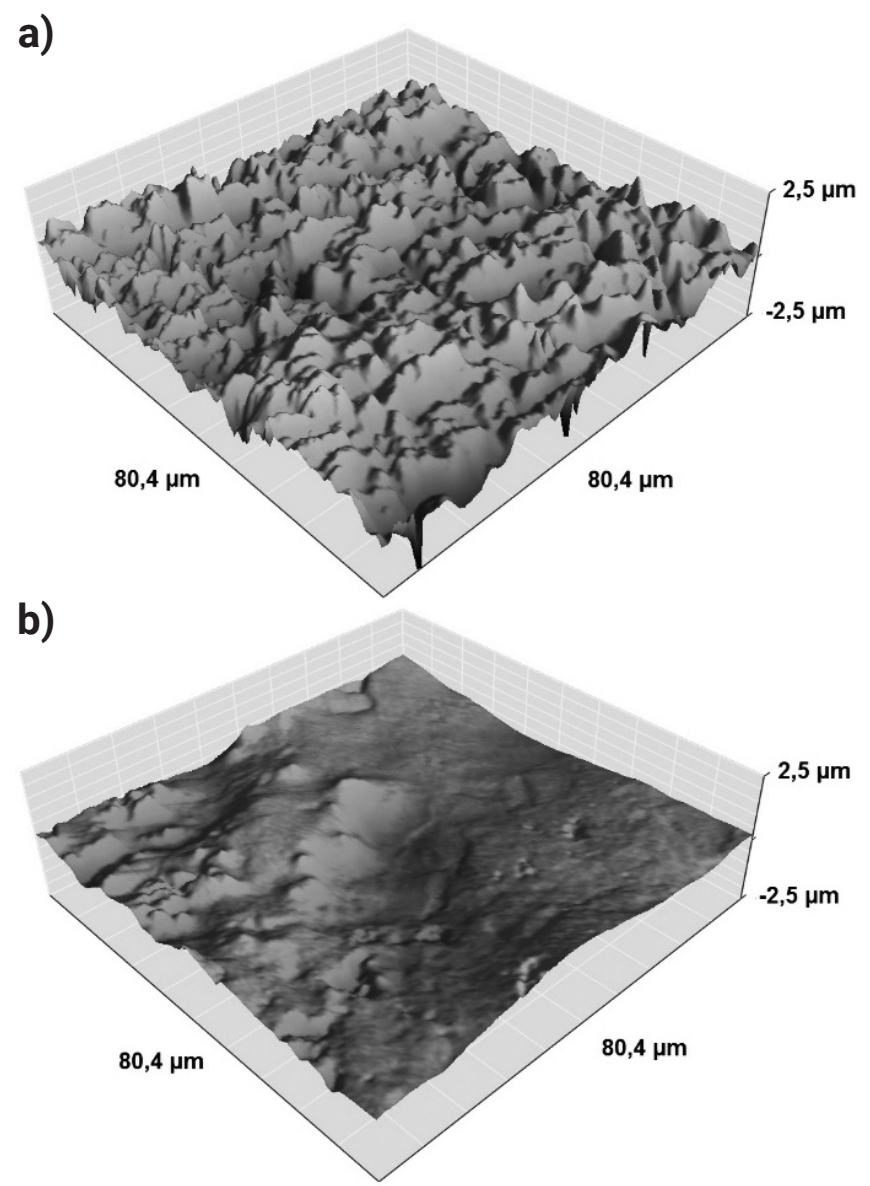

Rys. 3. Topografia powierzchni AFM próbki: a) MWCNT.laser.0,5ms, b) MWCNT.laser. $1 \mathrm{~ms}$

Fig. 3. AFM surface topography of the sample: a) MWCNT. laser.0,5ms, b) MWCNT.laser. $1 \mathrm{~ms}$ 
Tablica III. Uzyskane chropowatości powierzchni dla badanych próbek na podstawie badań mikroskopem AFM

Table III. Surface roughness based on AFM microscope measurement

\begin{tabular}{|c|c|}
\hline Oznaczenie próbki & Chropowatość powierzchni $\mathbf{S}_{\mathbf{a}}[\boldsymbol{\mu m}]$ \\
\hline MR & 0,197 \\
\hline MR.laser.0,5ms & 0,256 \\
\hline MR.laser.1ms & 0,158 \\
\hline MWCNT.laser.0,5ms & 0,329 \\
\hline MWCNT.laser.1ms & 0,190 \\
\hline
\end{tabular}

chwilowo wartości siły, tzw. krzywe histerezy obciążenie odkształcenie (wykres dla próbki referencyjnej z materiału rodzimego MR został pokazany na rys. 4). Obserwowane są trzy charakterystyczne etapy nanoindentacji.

Po uzyskaniu kontaktu wgłębnika z próbką następuje wzrost obciążenia do uzyskania maksymalnej wartości, gdzie następuje przetrzymanie wgłębnika w tej pozycji (stabilizacja maksymalnej głębokości penetracji wgłębnika). Ostatni etap to odciążanie.

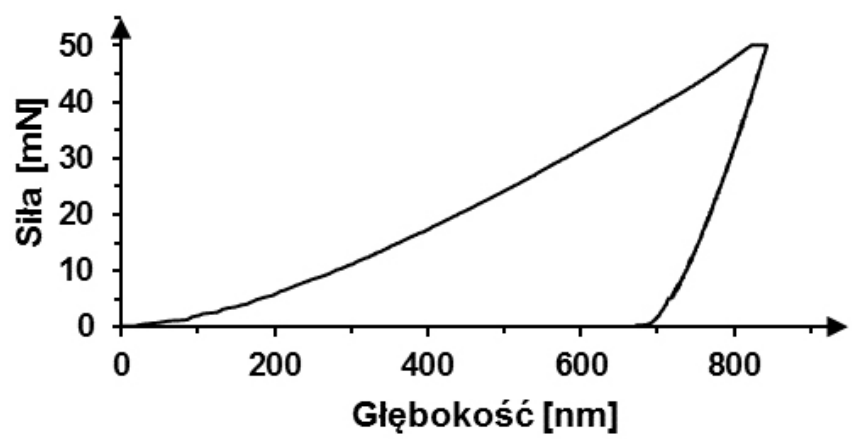

Rys. 4. Wykres histerezy obciążenie-odkształcenie dla próbki referencyjnej z materiału rodzimego (MR)

Fig. 4. Load-deformation hysteresis graph of the reference sample - native material (MR)

W tablicy IV przedstawiono wyniki badań nanoindentacji. Najwyższą nanotwardość oraz moduł Younga uzyskano dla powłoki wielościennych nanorurek węglowych poddanych obróbce laserowej z wykorzystaniem impulsów o długości $1 \mathrm{~ms}$ (MWCNT.laser.1ms). Właściwości tego materiału przewyższają właściwości mechaniczne materiału podłoża zarówno zmodyfikowanego laserowo, jak i bez obróbki. Czas trwania impulsu znacznie podwyższył parametry otrzymanej powłoki.

Długość trwania impulsu podczas obróbki laserowej wpływa również na głębokość penetracji sondy w badaną powierzchnię. Nanorurki poddane obróbce laserowej impulsami trwającymi 1 ms wykazały znacznie niższą maksymalną głębokość penetracji wgłębnika oraz lepszą równomierność rozkładu. Najmniejszą głębokość penetracji wgłębnika osiągnięto dla powłoki nanorurek węglowych poddanych obróbce laserowej z impulsem o długości $1 \mathrm{~ms}$, co jest związane z osiągnięciem przez próbkę MWCNT.laser.1ms najwyższej nanotwardości oraz modułu Younga. Z tablicy IV można wywnioskować, że wraz ze wzrostem nanotwardości i modułu Younga maleje głębokość penetracji wgłębnika w materiał.

$\mathrm{Na}$ rysunkach $5 \div 10$ przedstawiono rozkłady 3D modułu Younga oraz nanotwardości w celu lepszego zobrazowania właściwości mechanicznych podłoża przed oraz po obróbce, a także powłok $z$ wielościennych nanorurek węglowych po modyfikacji laserowej.
Rysunki $5 \div 7$ przedstawiają rozkłady 3D modułu Younga dla badanych materiałów. Na rysunku 5 pokazano, jak zmienia się moduł Younga stopu Ti13Nb13Zr po procesie szlifowania.

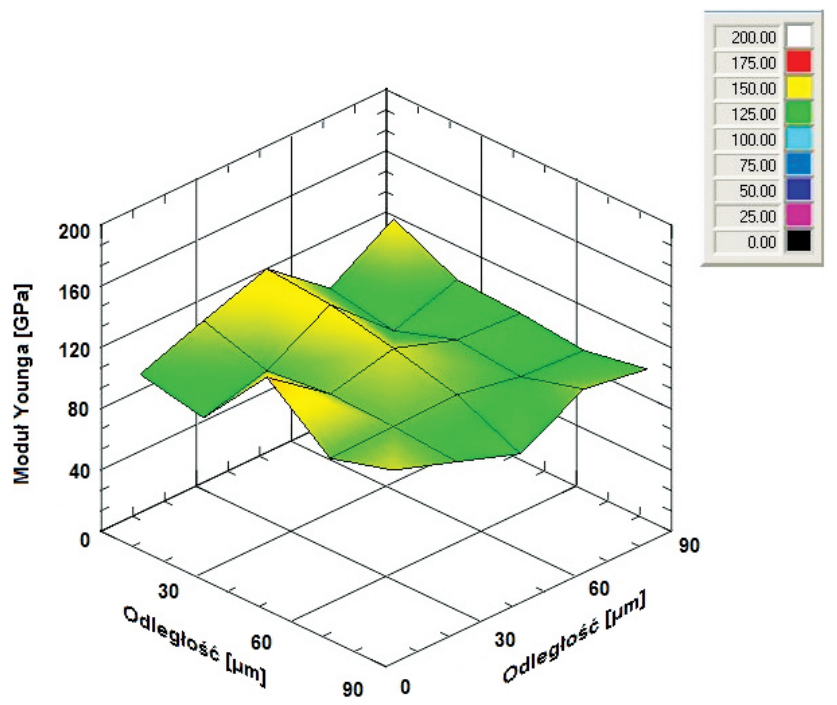

Rys. 5. Rozkład 3D modułu Younga próbki referencyjnej MR

Fig. 5. 3D Young modulus distribution of the MR reference sample

a)

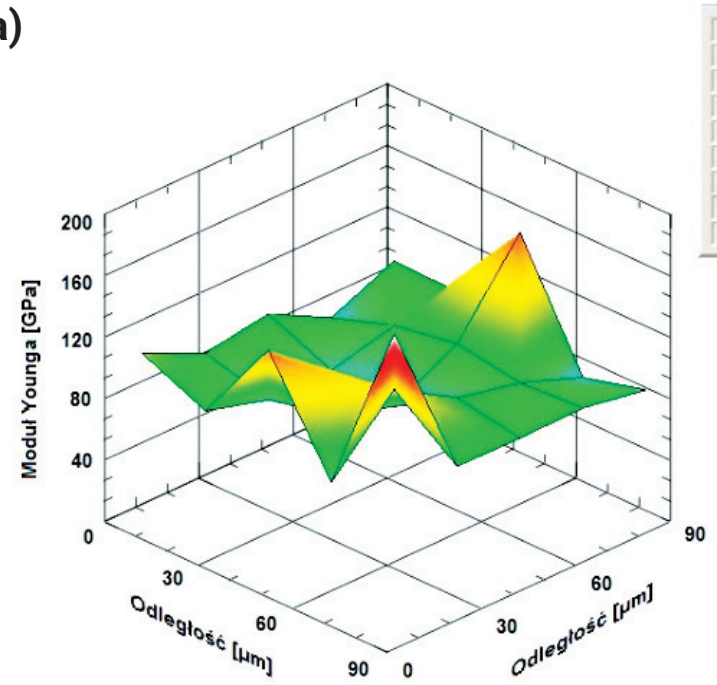

b)

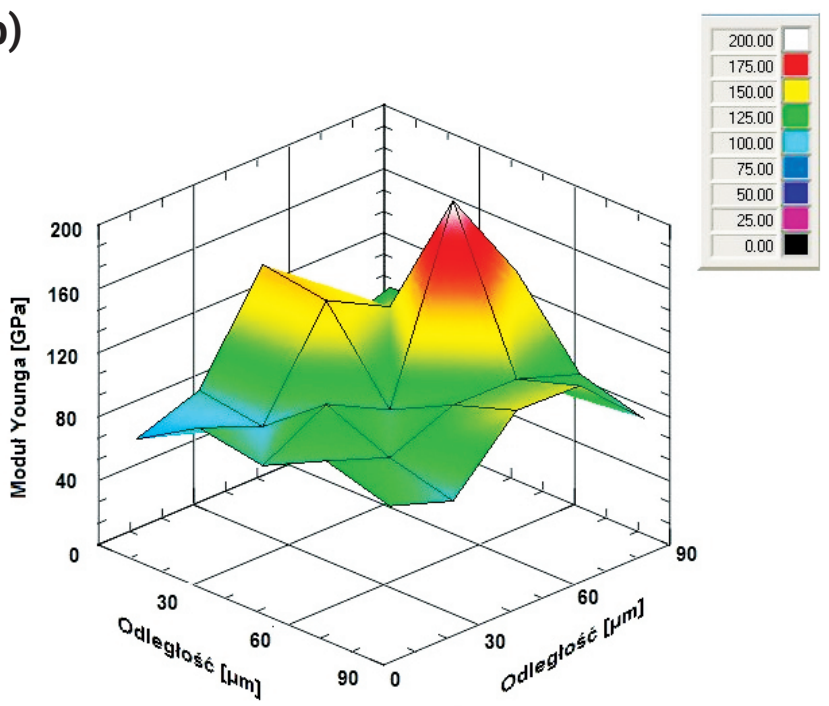

Rys. 6. Rozkład 3D modułu Younga próbki: a) MR.laser.0,5ms, b) MR.laser.1ms

Fig. 6. 3D Young modulus distribution of the sample: a) MR.laser.0,5ms, b) MR.laser. $1 \mathrm{~m}$ 
W przypadku wielościennych nanorurek węglowych pod danych obróbce laserowej (rys. 7) można zaobserwować, że wydłużenie czasu impulsu spowodowało wyrównanie rozkładu modułu Younga w obrębie badanej powierzchni.

Na rysunkach $8 \div 10$ zostały pokazane rozkłady 3D nanotwardości badanych materiałów, na podstawie których można wnioskować podobnie, jak przy analizie modulu Younga w przeprowadzonych badaniach.

a)
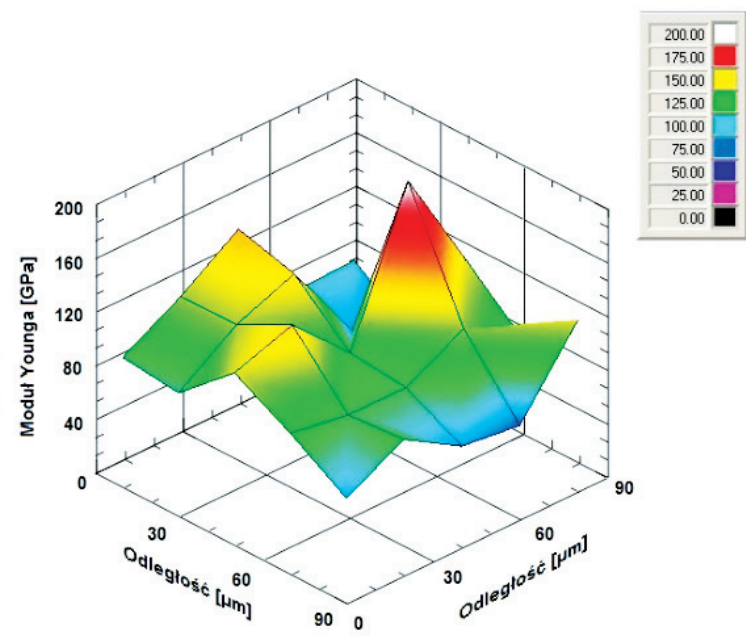

b)

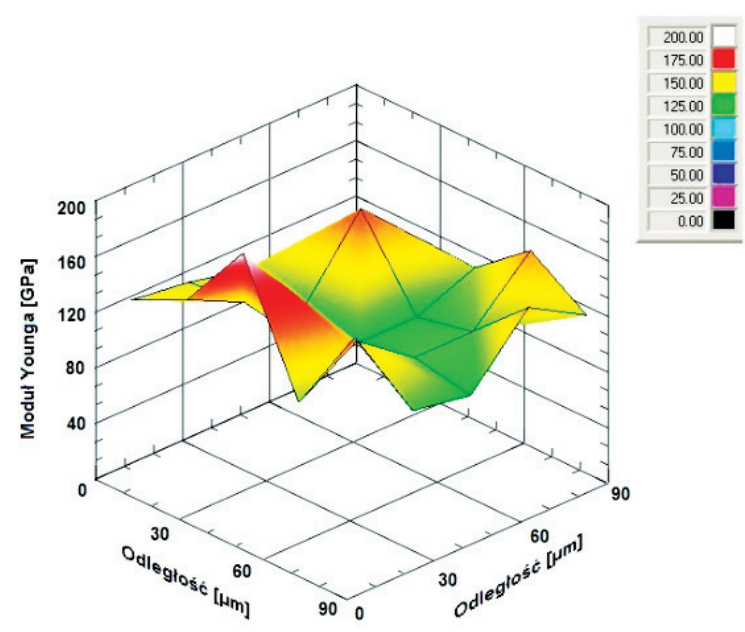

Rys. 7. Rozkład 3D modułu Younga próbki: a) MWCNT.laser.0.5ms, b) MWCNT.laser.1ms

Fig. 7. 3D Young modulus distribution of the sample: a) MWCNT. laser.0.5ms, b) MWCNT.laser. $1 \mathrm{~ms}$
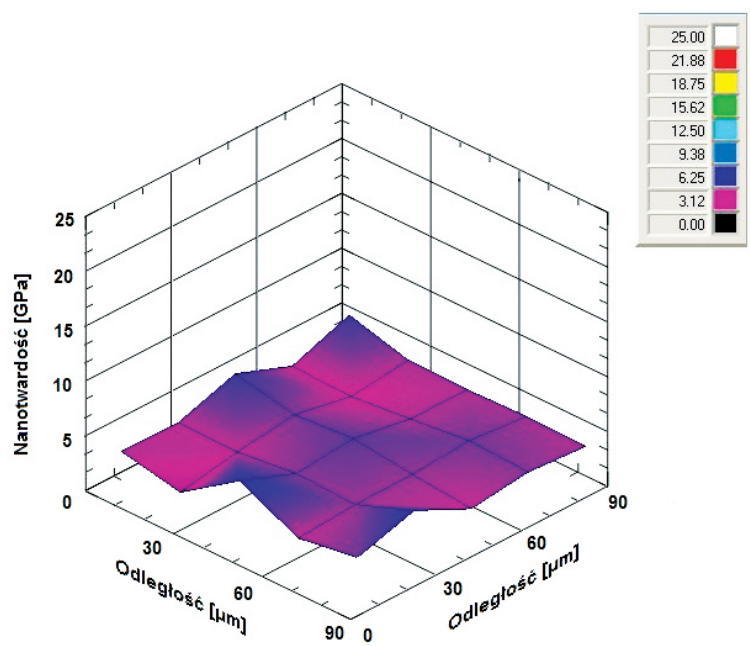

Rys. 8. Rozkład 3D nanotwardości próbki referencyjnej MR

Fig. 8. 3D distribution of the nanohardness of the MR reference sample a)
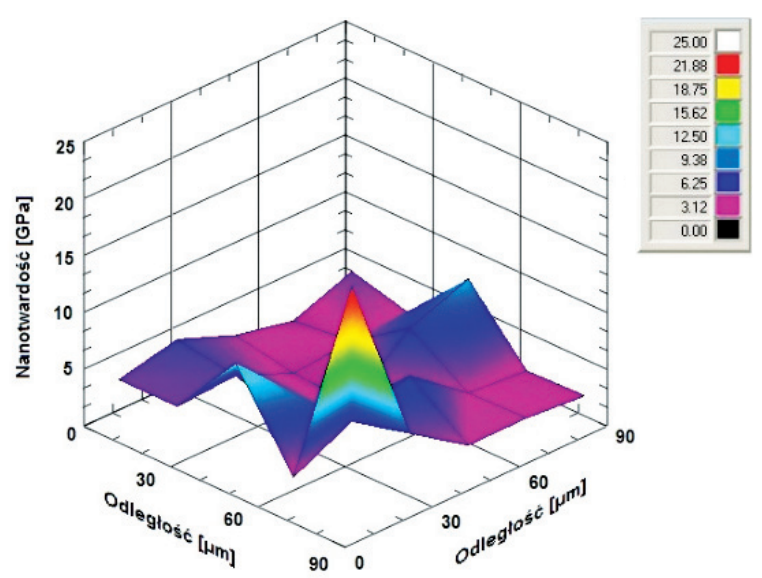

b)

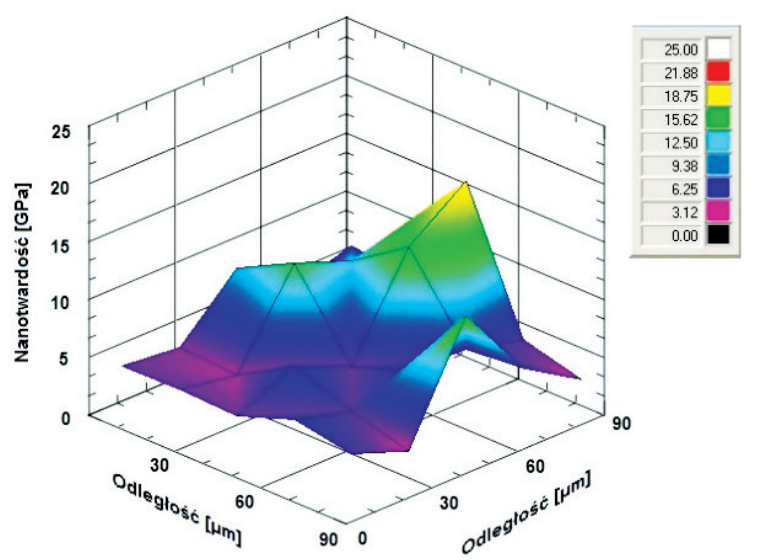

Rys. 9. Rozkład 3D nanotwardości próbki: a) MR.laser.0,5ms, b) MR.laser.1ms

Fig. 9. 3D nanohardness distribution of the sample: a) MR.laser.0,5ms, b) MR.laser.1ms

a)
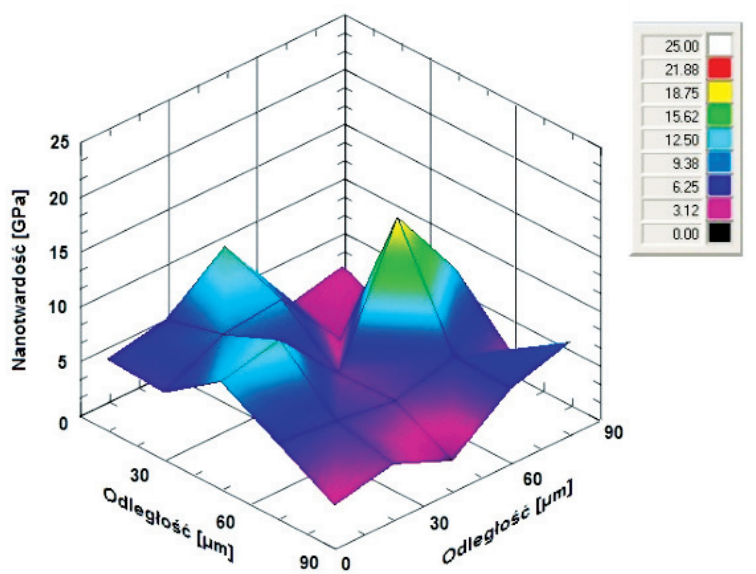

b)
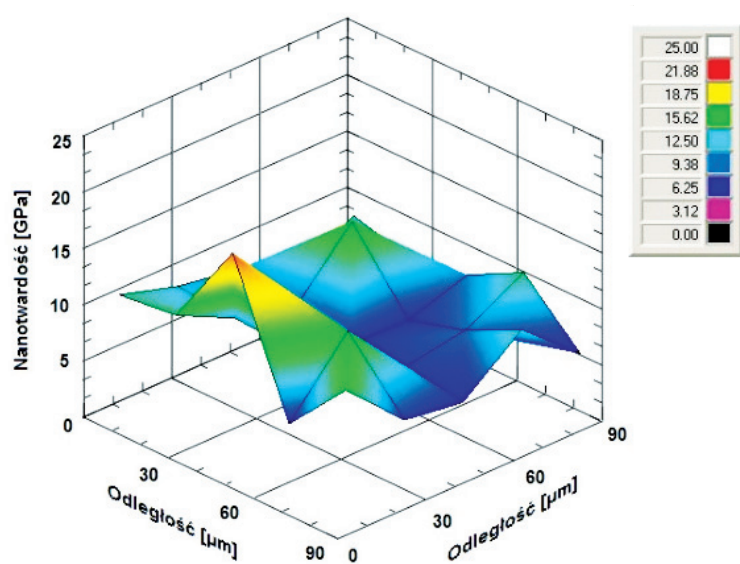

Rys. 10. Rozkład 3D nanotwardości próbki: a) MWCNT.laser.0,5ms, b) MWCNT.laser.1ms

Fig. 10. 3D nanohardness distribution of the sample: a) MWCNT. laser.0,5ms, b) MWCNT.laser. $1 \mathrm{~ms}$ 
Tablica IV. Zestawienie właściwości mechanicznych podłoża dla otrzymanych powłok wraz z maksymalną głębokością penetracji wgłębnika w materiał

Table IV. Mechanical properties of the substrate and achieved coatings with maximum depth of the indenter

\begin{tabular}{|c|c|c|c|c|}
\hline Oznaczenie próbki & Nanotwardość [GPa] & $\begin{array}{c}\text { Zredukowany } \\
\text { Moduł Younga [GPa] }\end{array}$ & Moduł Younga [GPa] & $\begin{array}{c}\text { Maksymalna głębokość } \\
\text { penetracji wgłębnika [nm] }\end{array}$ \\
\hline MR & $3,96 \pm 0,85$ & $108,90 \pm 12,49$ & $77,01 \pm 8,83$ & $813,01 \pm 78,71$ \\
\hline MR.laser.0,5ms & $5,11 \pm 4,08$ & $102,93 \pm 33,16$ & $72,37 \pm 23,32$ & $804,89 \pm 173,33$ \\
\hline MR.laser.1ms & $6,63 \pm 3,38$ & $104,03 \pm 30,34$ & $73,22 \pm 21,36$ & $696,41 \pm 131,05$ \\
\hline MWCNT.laser.0,5ms & $5,88 \pm 3,32$ & $99,53 \pm 33,94$ & $81,74 \pm 27,87$ & $773,36 \pm 240,00$ \\
\hline MWCNT.laser.1ms & $8,88 \pm 3,02$ & $124,24 \pm 25,64$ & $104,50 \pm 21,57$ & $584,33 \pm 78,92$ \\
\hline
\end{tabular}

\section{Podsumowanie}

Modyfikacja laserowa stopu Ti13Nb13Zr bez dodatkowej powłoki węglowej spowodowała nieznaczne zwiększenie właściwości, takich jak nanotwardość i moduł Younga w porównaniu z materiałem bez obróbki. Wydłużenie czasu trwania impulsu z 0,5 ms do 1,0 ms spowodowało nieznaczną poprawę badanych właściwości mechanicznych stopu Ti13Nb13Zr.

Modyfikacja laserowa badanego stopu z powłoką z wielościennych nanorurek węglowych oraz wydłużenie czasu trwania impulsu z 0,5 ms do 1 ms wpłynęło na zwiększenie właściwości mechanicznych (nanotwardości oraz modułu Younga) w porównaniu do materiału podłoża. Nanotwardość wzrosła ponad dwukrotnie po zastosowaniu stopowania z użyciem nanorurek węglowych.

Ponadto, w zależności od czasu trwania impulsu można zaobserwować zmianę wartości parametru chropowatości Sa. Powierzchnia stopu Ti13Nb13Zr modyfikowana laserowo z użyciem impulsów o czasie trwania równym 0,5 ms może charakteryzować się zwiększoną chropowatością, w stosunku do modyfikacji laserowej przy czasie trwania impulsów równym $1 \mathrm{~ms}$. Zastosowanie dłuższego czasu impulsu lasera Nd:YAG powoduje ujednolicenie właściwości w obrębie badanej powierzchni. Jednorodność właściwości mechanicznych ma istotne znaczenie $\mathrm{w}$ przewidywaniu zachowania materiału pod wpływem różnych obciążeń.

\section{Literatura}

[1] Marciniak J.: Biomateriały, Wydawnictwo Politechniki Śląskiej, Gliwice 2013.

[2] http://zasoby1.open.agh.edu.pl/dydaktyka/chemia/a_e_chemia/1_3_ budowa_materii/01_04_03_2b.htm [dostęp:20.05.2018]

[3] Dresselhaus M. S., Dresselhaus G., Avouris P.: Carbon Nanotubes: Synthesis, Structure, Properties, and Applications. Springer-Verlag Berlin $\mathrm{He}-$ idelberg 2001.

[4] Bachmatiuk A.: Praca doktorska: Badania nad technologią otrzymywania i właściwościami nanorurek węglowych, Politechnika Szczecińska. Wydział Technologii i Inżynierii Chemicznej. Instytut Technologii Chemicznej Nieorganicznej i Inżynierii Środowiska, Szczecin 2008.

[5] Dlugon E., Simka W., Franczek-Szczypta A., Niemiec W., Markowski J., Szymanska M., Blazewicz M.: Carbon nanotube-based coatings on titanium, Bull. Mater. Sci., Vol. 38, No. 5, September 2015, pp. 1339-1344.

[6] Bartmański M., Berk A., Wójcik A.: The Determinants of Morphology and Properties of the Nanohydroxyapatite Coating Deposited on the Ti13Nb13Zr Alloy by Electrophoretic Technique, Advances in Materials Science, Vol. 16, No. 3 (49), 2016.

[7] Sidun J., Dąbrowski J. R.: Aspekty biomechaniczne uszkodzeń minipłytek zespalających kości twarzoczaszki, MOTROL, 2009, 11c, s. 176-181.

[8] Niinomi M., Narushima T., Nakai M.: Advances in Metallic Biomaterials, Tissues, Materials and Biological Reactions, Springer Series in Biomaterials Science and Engeenering, 2015.

[9] Voggenreiter G., Leiting S., Brauer H., Leiting P., Majetschak M., Bardenheuer M., Obertacke U.: Immuno-inflammatory tissue reaction to stainless-steel and titanium plates used for internal fixation of long bones, Biomaterials 24, 2003, pp. 247-254.
[10] Besra L., Liu M.: A review on fundamentals and applications of electrophoretic deposition (EPD). Progress in Materials Science 52, 2007, pp. 1-61.

[11] Yamaguchi T., Hagino H.: Formation of titanium carbide layer by laser alloying with a light-transmitting resin. Optics and Lasers in Engineering 88, 2017, pp. 13-19.

[12] Borek A., Grzelka R., Klimpel A., Mucha S., Ścibisz B.: Technologie laserowe spawania, wytwarzania i obróbki cieplnej warstw wierzchnich, Przegląd Spawalnictwa vol. 85, nr 10, 2013.

[13] Makuch N., Kulka M., Dziarski P., Przestacki D.: Laser surface alloying of commercially pure titanium with boron and carbon. Optics and Lasers in Engineering 57, 2014, pp. 64-81.

[14] Miklaszewski A., Kaczmarek M., Jurczyk M. U.: Powierzchniowe stopowanie mikroplazmowe jako nowe podejście w zakresie modyfikacji biomateriałów tytanowych, Przegląd Spawalnictwa vol. 89, nr 10, 2017.

[15] Filip R.: Kształtowanie mikrostruktury warstwy wierzchniej stopu tytanu Ti-6Al-4V poprzez stopowanie laserowe, Inżynieria Materiałowa 5, 2005.

[16] Filip R.: Alloying of surface layer of the Ti-6Al-4V titanium alloy through the laser treatment. Journal of Achievements in Materials and Manufacturing Engineering, vol. 15, 1-2, 2006.

[17] Michalak M., Łatka L., Sokołowski P.: Porównanie właściwości mechanicznych powłok natryskiwanych plazmowo proszkowo I z zawiesin. Przegląd Spawalnictwa, vol. 89 nr 10, 2017. 